\title{
Use of a Tissue Blotting Immunoassay to Examine the Distribution of Pineapple Closterovirus in Hawaii
}

\author{
J. S. Hu, D. M. Sether, X. P. Liu, and M. Wang, Department of Plant Pathology, University of Hawaii, Honolulu \\ 96822; F. Zee, USDA-ARS, National Clonal Germplasm Repository, Hilo, HI; and D. E. Ullman, Department of \\ Entomology, University of California, Davis 95616
}

\begin{abstract}
Hu, J. S., Sether, D. M., Liu, X. P., Wang, M., Zee, F., and Ullman, D. E. 1997. Use of a tissue blotting immunoassay to examine the distribution of pineapple closterovirus in Hawaii. Plant Dis. 81:1150-1154.

Specific monoclonal antibodies made to a pineapple closterovirus (PCV) were used in a tissue blotting immunoassay (TBIA) for the detection of PCV in pineapple. More than 2,000 samples were tested in 5 days by one person using this rapid and reliable assay. A survey was conducted using this assay to test more than 20,000 Hawaiian pineapple samples for the presence of PCV. PCV was detected in symptomless pineapple plants in the field and in the USDA pineapple germ plasm collection. Studies of the association of PCV with mealybug wilt of pineapple (MWP) suggest that PCV may be involved in MWP.
\end{abstract}

Mealybug wilt of pineapple (MWP) is a serious disorder that nearly destroyed the Hawaiian pineapple industry in the early 1900s $(1,4,11)$. Although this disease has been reported throughout the world and has posed a significant threat to the pineapple industry for more than 80 years, its etiology is still unknown $(4,11)$. Several hypotheses have been proposed regarding possible causes of MWP; one suggested that mealybugs secreted a toxin during feeding (1) and another proposed a viral etiology (2). In 1989, closterovirus-like particles were purified from diseased Hawaiian pineapple tissue and partially characterized (5). More recently, pineapple closterovirus-like virions (PCV) serologically related to the Hawaiian isolate were purified from diseased pineapple in Australia (13).

Several factors have complicated the elucidation of PCV's role in the etiology of MWP. Like many other closteroviruses, PCV is phloem-limited, occurs at very low titers, and is not mechanically transmissible (J. S. Hu, unpublished). These characteristics led to low yields of purified virus and hampered the development of sensitive and reliable detection methods. The host range of PCV appears to be limited to pineapple. Assays based on doublestranded RNA (dsRNA) analysis are useful but not practical for screening large numbers of samples $(5,7)$. Polyclonal antibod-

Corresponding author: J. S. Hu

E-mail: johnhu@hawaii.edu

Accepted for publication 19 June 1997.

Publication no. D-1997-0807-02R

(C) 1997 The American Phytopathological Society ies (PAb) produced in Hawaii and Australia against partially purified PCV have been used in ISEM to detect PCV $(12,13)$. However, these PAb also reacted to pineapple plant proteins and thus were not useful in enzyme-linked immunosorbent assay (ELISA). Recently, monoclonal antibodies were produced for detection of the Hawaiian isolate of PCV and used in double antibody sandwich indirect ELISA to detect PCV in pineapple plants and mealybugs (9). However, the assay lacked adequate sensitivity, and pineapple root samples or partially concentrated pineapple leaf samples had to be used (9). The objectives of the present study were to develop a rapid and reliable assay for processing large numbers of samples and to apply the assay to study the distribution of PCV in pineapple in Hawaii.

\section{MATERIALS AND METHODS}

Tissue blot immunoassay (TBIA). Leaves from the stems of pineapple plants were used as samples in tissue blot immunoassays. In the case of plants bearing fruits (parent plants), leaves from the vegetative crowns produced atop the fruits were also sampled. A razor blade was used to make transverse cuts across the white portion of each leaf base to make an even edge. This freshly cut edge was firmly pressed onto $0.45 \mu \mathrm{m}$ Nitro ME nitrocellulose membrane (Micron Separations, Inc., Westboro, MA) for 3 to $5 \mathrm{~s}$. Sequential cuts were made up the leaf, and the freshly cut edges were blotted onto the membrane for studies of PCV distribution within leaves. Analysis of PCV distribution throughout the plant was made by sequentially removing and blotting leaves from crowns, floral shoots, and floral bracts. The stem and roots were also cut transversely at approximately $1-\mathrm{cm}$ increments and then blotted as above. The impression of the vascular leaf bundles remained on the membrane after blotting. Membranes were stored dry at room temperature between paper towels until analyzed. Immobilon P (Millipore, Bedford, MA) and Nitropure (Micron Separations, Inc.) membranes were also tested.

Blotted membranes were placed in a plastic container and blocked with $2 \%$ (wt/vol) powdered milk dissolved in TBS buffer (50 mM Tris-CHl, $50 \mathrm{mM} \mathrm{NaCl}, \mathrm{pH}$ 7.5) for $30 \mathrm{~min}$ at room temperature. Membranes were then incubated in a new plastic container or sealable plastic bag with $1 \mu \mathrm{g}$ of PCV 35-6-5 or 63-1-2 monoclonal antibodies per $\mathrm{ml}$ (9) in TBS with gentle agitation at room temperature for 1 to $2 \mathrm{~h}$, followed by an overnight soak at $4^{\circ} \mathrm{C}$. Membranes were washed in three changes of room temperature TBST (TBS $+0.5 \%$ Tween 20) for 10 min each with constant agitation and then were incubated with goat anti-mouse (GAM) alkaline phosphatase conjugate (Sigma Chemical Co. St. Louise, MO) at 1:1,000 dilution in TBS for 2 to $3 \mathrm{~h}$ at room temperature. Membranes were washed as described above, placed in hybridization bottles with alkaline phosphatase substrate (Sigma Fast BCIP/NBT tablets, B5655), and rotated in a hybridization oven at room temperature for up to $1 \mathrm{~h}$, then rinsed in distilled water and allowed to air dry.

Alternatively, the entire procedure was done by placing membranes in hybridization bottles with or without nylon mesh. All of the blocking, antibody incubation, substrate, and wash steps described above were performed in a rotating hybridization oven. After membranes were dry, the extent of the serological reactions was determined under a dissecting microscope.

In some experiments, membranes were blocked as described above and incubated simultaneously with $1 \mu \mathrm{g}$ of PCV 35-6-5 or 63-1-2 monoclonal antibodies per $\mathrm{ml}$ and GAM conjugate at a dilution of 1:1,000 in TBS. These membranes were gently agitated at room temperature for $4 \mathrm{~h}$. Membranes were washed in PBST and incubated with the substrate as described previously. Using these methods, the effect of membrane storage time, distribution of PCV within pineapple plants, and detection of PCV in consecutive imprints of a single cut surface were studied. 
Surveys. Leaves from the crowns of fruiting pineapple plants were sampled for surveys of symptomless, commercially grown varieties and hybrids. If fruiting was not yet initiated, leaves from the upper third (youngest) portion of the plant were sampled. Samples from fields with ages between planting until first harvest are referred to as plant crop samples. Samples from fields with plants between first and second harvest are referred to as first ratoon samples. All leaf samples were collected on the islands of Oahu and Maui and were blotted within $20 \mathrm{~h}$ after collection as described above.

A separate survey comparing the PCV status of symptomatic and symptomless plants of the same cultivars growing in close proximity to one another was also conducted. Typical leaf symptoms included reddening, tip dieback, and wilting. Approximately 700 leaf samples were collected from a total of about 500 symptomatic and symptomless plants at various developmental stages. Three sampling times were selected based upon developmental stage. Leaves were sampled from the upper one-third of prefruiting plant crop plants 3 months after they were forced to flower. Forcing is the standard industry practice of spraying plants with a compound to induce blooming. A second set of plant crop plants with fruits and crowns was sampled 6 months postforcing. Leaves from both the fruiting parent plants and the crowns were sampled. The third set of leaf samples was collected from prefruiting first ratoon plants.

In addition, 173 accessions of pineapple and related species, maintained in greenhouses at the USDA-ARS National Clonal Germplasm Repository in Hilo, Hawaii, were screened for PCV. Each accession was represented by two plants; both, if available, were screened and tested in January and April 1996. Controls for all tests included leaves from PCV-infected and PCV-free pineapple plants.

\section{RESULTS}

Development of the assay. PCV-specific monoclonal antibodies showed strong reactions to $\mathrm{PCV}$ antigens in infected leaves and no cross-reactivity to healthy plants on membrane blots (Fig. 1). Intense deep-purple staining was clearly visible in the vascular bundles of PCV-infected leaves. PCV antigen appeared to be limited to the vascular bundles. Polyclonal antibodies to a Hawaiian isolate of PCV were also tested but reacted to pineapple proteins, making it unsuitable for use in TBIA (data not shown).

PCV antigen was detected with TBIA in young and middle-aged leaves, as well as in roots, but not in old leaves (Fig. 2A and B). Within individual leaves, virus was present in the green leaf lamina, the basal white tissue, and the interface between these two tissues. The basal white tissue of leaves was found to be most reliable for routine detection (Fig. 2A). When plants were bearing fruit, detection of PCV antigen was most reliable when the leaves from the vegetative crowns were used (Table 1). The strongest labeling was found in vascular tissues of adventitious roots within the cortex of the stem (Fig. 3A). Labeling was not observed in PCV-free pineapple plants (Fig. 3B).

Various membranes were tested, and differences in performance were observed (Fig. 4). Imprints of the cut leaf edge and inner vascular bundles, caused by the physical compression of the membrane, were useful visual marks to direct sample placement and to facilitate the interpretation of results when reactions were weak. Leaf imprints were difficult to see on $\mathrm{Ni}$ tropure and Immobilon P but were readily identifiable on Nitro ME membranes (Fig. 4A I to III, respectively). In addition, the purple color was more intense on Nitro ME membranes (Fig. 4A III). Based on these observations, the Nitro ME mem-

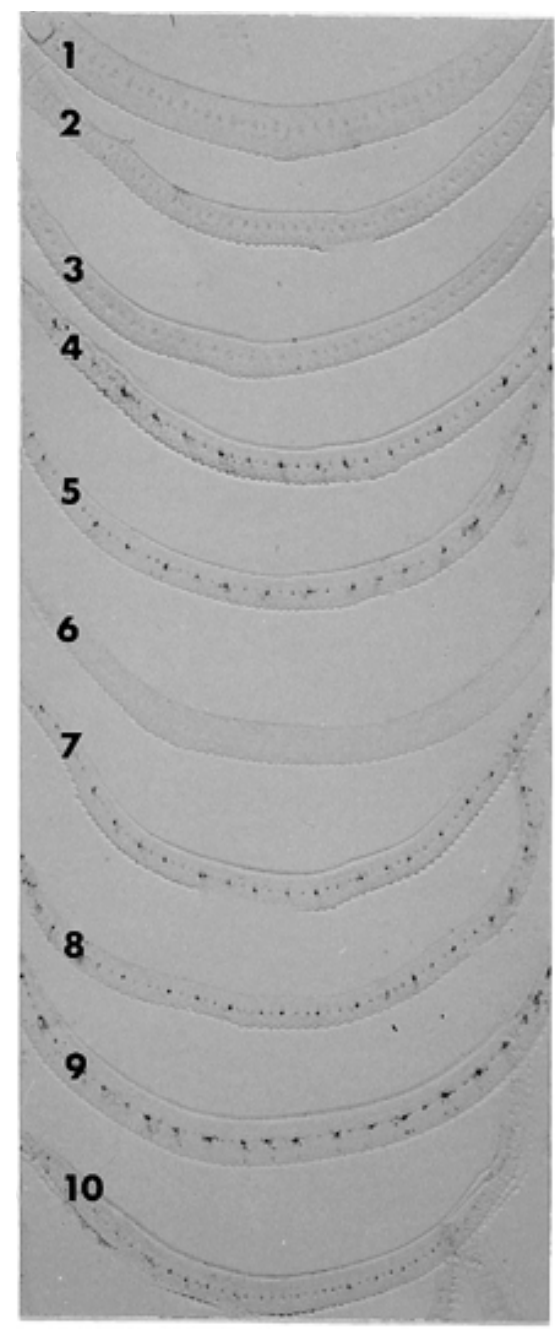

Fig. 1. Tissue blots of cross-sectioned healthy $(1,2,3,6)$ and pineapple closterovirus (PCV)infected $(4,5,7,8,9,10)$ pineapple leaves. The blots were probed with anti-PCV monoclonal antibody. brane was chosen as the standard for this procedure. Membranes blotted with the same leaf samples and assayed either 1 day or 45 days after blotting gave comparable results (Fig. 4B I and II, respectively). Also, PCV antigen was detected in consecutive blots (up to 13) made from the same cut tissue surface (Fig. 4C).

Membrane blots processed in plastic containers or heat-sealable plastic bags yielded reproducible results with little background. In contrast, those processed using a hybridization oven and bottles for antibody and wash steps, with or without mesh screens, gave erratic results, with very poor detection levels and/or high backgrounds. Using clean nylon mesh screens, bottles, and caps after each step did not reduce backgrounds. However, use of a hybridization oven and bottles for the substrate step was effective and allowed the use of minimum amounts of substrate.

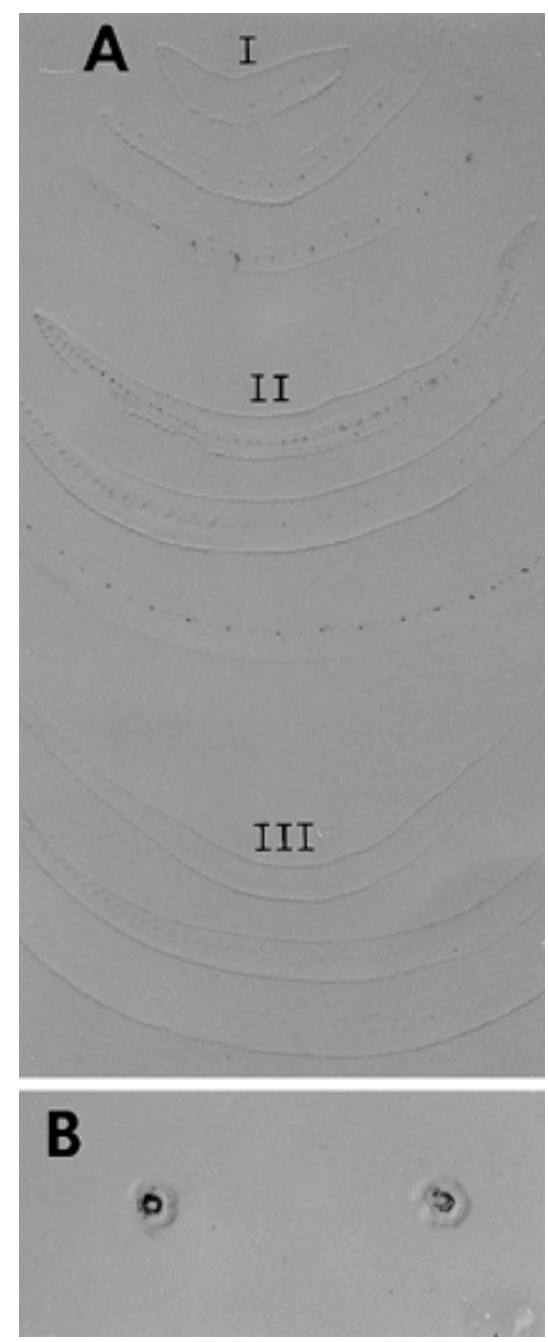

Fig. 2. Examination of distribution of pineapple closterovirus (PCV) in PCV-infected pineapple plants using tissue blotting immunoassay. (A) Samples were from green (top), interface (middle), and white (bottom) portions of the young (I), medium (II), and old (III) leaves. (B) Cross sections of roots from the same plants. The blots were probed with anti-PCV monoclonal antibody. 
Membranes incubated simultaneously with PCV monoclonal antibodies and GAM conjugate gave identical results with those blots incubated separately with the antibody and conjugate (data not shown). Simultaneous incubation with
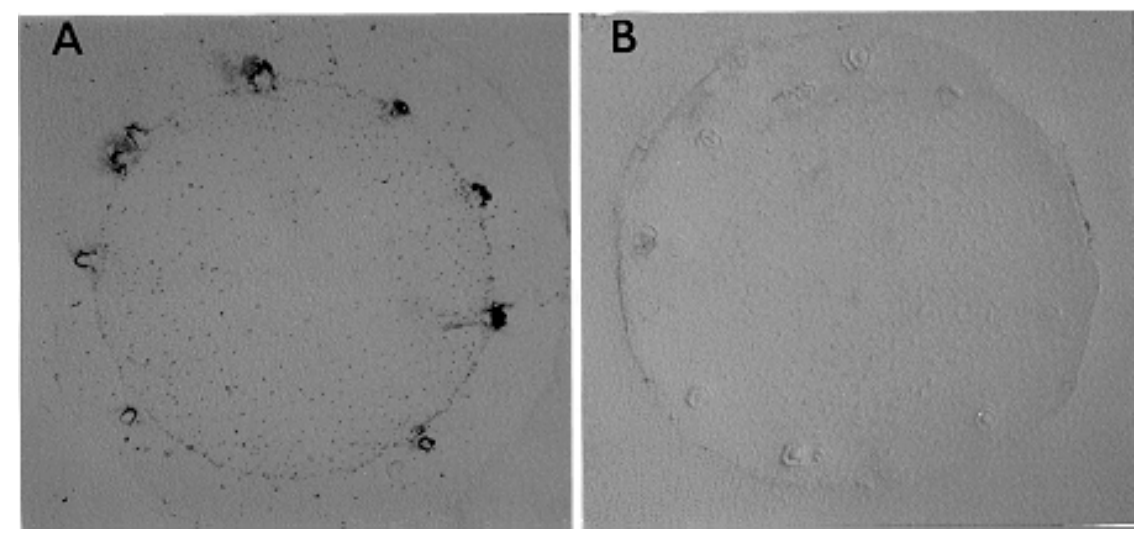

Fig. 3. Detection of pineapple closterovirus (PCV) using tissue blotting immunoassay in a cross section made through the basal portion of (A) PCV-infected pineapple stem and (B) PCV-free pineapple stem. The blots were probed with anti-PCV monoclonal antibody.

Table 1. Detection of pineapple closterovirus (PCV) in pineapple plants in Hawaii ${ }^{\mathrm{y}}$

\begin{tabular}{llcc}
\hline Plant materials & MWP status & No. PCV+/no. tested & $\%$ PCV + \\
\hline Plant crop & & & \\
3 months postforce & & & 35 \\
$\quad$ Leaves from plants & Symptomless & $40 / 114$ & 92 \\
& Symptomatic & $67 / 73$ & 31 \\
6 months postforce & & $31 / 100$ & 33 \\
Leaves from parents & Symptomless & $33 / 100$ & 49 \\
$\quad$ Leaves from respective crowns & & $35 / 73$ & 99 \\
Leaves from parents & Symptomatic & $72 / 73$ & 32 \\
Leaves from respective crowns & & $32 / 101$ & 56 \\
First ratoon & & $46 / 82$ & \\
$\quad$ Leaves from parents & Symptomless & & \\
& Symptomatic &
\end{tabular}

y Samples were collected from pineapple plants showing symptoms of mealybug wilt of pineapple (MWP) and those showing no symptoms but growing in close proximity to symptomatic plants.

${ }^{\mathrm{z}}$ Leaf samples from parents and crowns were collected from the same plants.

Table 2. Detection of pineapple closterovirus (PCV) from symptomless pineapple plants using specific monoclonal antibodies in tissue blotting immunoassay

\begin{tabular}{lccccc}
\hline Plant & Status $^{\mathbf{x}}$ & Total samples & Total fields & \multicolumn{2}{c}{$\begin{array}{c}\text { Mean } \pm \mathbf{S E}^{\mathbf{y}} \\
\text { across fields }\end{array}$} \\
\hline Cultivar 1 $^{\mathbf{z}}$ & C/PC & 9,717 & 9 & 20 & 4 \\
& C/R & 222 & 2 & 13 & 6 \\
Cultivar 2 & P/R & 427 & 4 & 21 & 8 \\
Cultivar 3 & C/PC & 3,623 & 4 & 45 & 7 \\
Cultivar 4 & P/PC & 114 & 1 & 35 & \\
Cultivar 5 & C/PC & 629 & 3 & 60 & 6 \\
& C/PC & 372 & 3 & 90 & 4 \\
& C/PC & 1,548 & 7 & 100 & 0 \\
Hybrid 1 & P/PC & 611 & 4 & 100 & 0 \\
& C/R & 711 & 5 & 100 & 0 \\
Hybrid 2 & P/R & 786 & 7 & 100 & 0 \\
& C/PC & 125 & 1 & 0 & \\
Hybrid 3 & P/PC & 260 & 2 & 0 & 0 \\
& C/PC & 536 & 1 & 11 & \\
& P/PC & 220 & 2 & 9 & 1 \\
& C/PC & 498 & 1 & 19 & 5 \\
\hline
\end{tabular}

${ }^{\mathrm{x}}$ Leaf material sampled was from crowns (C) or pre-fruit-bearing plants (P). Age of plants was plant crop (PC) or ratoon (R).

${ }^{y}$ Means of percentage of samples tested positive for PCV \pm standard error between fields.

${ }^{\mathrm{z}}$ Due to the proprietary nature of the commercially grown cultivars and hybrids, they were identified by number involving eight commercial cultivars and hybrids were tested. Due to the proprietary nature of the commercially grown cultivars and hybrids, these were identified by number. Among these, $100 \%$ of the samples of cultivar 5 and about $90 \%$ of the samples of cultivar 4 tested positive for PCV (Table 2). Incidences of PCV in other cultivars and hybrids ranged from 10 to $60 \%$. Hybrid 1 was PCV negative in all samples tested (Table 2).

Among 173 accessions of pineapple and related species maintained at the USDAARS National Clonal Germplasm Repository in Hilo, 71\% (102/144) of the Ananas comosus accessions were positive for PCV in at least one of the two plants tested. Only 19\% (4/21) of Ananas species other than A. comosus tested positive for PCV. These four positive samples included two of nine A. bracteatus and two of six $A$. ananassoides accessions. All samples from two collections of A. erectifolius (four plants), two of A. nanus (four plants), one Pseudoananas sagenarius (two plants), and one hybrid (two plants) of Cayenne $x$ $P$. sagenarius were PCV negative. These accessions were tested twice at 3-month intervals. All samples that tested positive or negative for PCV tested the same at the second sampling.

An important aspect of this investigation was the application of TBIA to examine the association of PCV with MWP. More than 700 pineapple leaf samples were tested by TBIA. These samples were collected from plants of the same cultivars with or without symptoms growing in close proximity to one another in pineapple fields. Overall, 49 to $99 \%$ of the samples from MWP-symptomatic plants tested positive for PCV, while 31 to $35 \%$ of the samples from asymptomatic plants tested positive (Table 1). When samples were divided into parent plants and corresponding crowns, $49 \%$ of the MWP symptomatic parent plants tested positive for $\mathrm{PCV}$, whereas $99 \%$ of the crowns from these parents were positive. Virus detection in asymptomatic plants and their crowns were 31 and $33 \%$, respectively.

\section{DISCUSSION}

Our results demonstrate that TBIA is a rapid and reliable assay for detection of PCV in pineapple tissues, allowing an individual to test more than 2,000 samples within 1 week. To detect PCV in pineapple leaf samples, TBIA was less labor intensive and more sensitive than ELISA, which required concentrated leaf samples to reliably detect PCV infections (9). In TBIA, young leaves from pineapple plants or crowns were used, and samples required little preparation. Our results show that the basal white portion of a pineapple leaf is better to use than the green leaf blade because of stronger reactions with lower background. This assay provides an ideal way to ship blotted membranes to a remote 
site for testing, because tissue imprints made on Nitro ME membrane could be stored at room temperature for at least 8 weeks without loss of sensitivity. Results obtained in TBIA were reliable because comparable results were obtained when samples from the same plant were repeatedly tested (data not shown). The assay was also successfully used to select plants or plant parts containing high virus titers for virus purification.

TBIA was first described by Lin et al. (10) for detection of several viruses and phytoplasmas. It has since been used to detect tomato spotted wilt tospovirus (6) and citrus tristeza closterovirus (3). The assay has several advantages over ELISA and immuno dot-blot assays. It does not require elaborate sample preparation or extraction, and it provides information on the distribution of virus in plant tissues. The assay can be done without any labeling or conjugation of antibodies. It does not require manifolds or other loading devices. It provides a convenient method to ship samples for testing between countries without live tissues. Sensitivity, assay time, and costs compare favorably with other serological assays. The major disadvantage of TBIA is that it cannot be readily quantified. We have used this assay successfully to detect potexviruses, tobamoviruses, tospoviruses, closteroviruses, geminiviruses, and potyviruses (J. S. Hu and X. P. Liu, unpublished).

Our survey results show that PCV is widespread in symptomless pineapple plants in Hawaii on plantations. The per- centage of PCV-positive plants, however, was found to vary between cultivars and hybrids (Table 2). Samples from particular cultivars were always PCV positive (100\% infection), while less than $20 \%$ of the samples from other cultivars were PCV positive. The percentage of PCV-positive plants in hybrids was lower than in cultivars. For example, $100 \%$ of the samples from one hybrid tested free of PCV. The hybrids that were tested are of relatively recent origin compared with the cultivars, so the low virus incidence among them may be due to less time for exposure to virus inoculum in field situations. The detection rate within each cultivar or hybrid was consistent, as indicated by the relatively small standard errors among fields (Table 2).

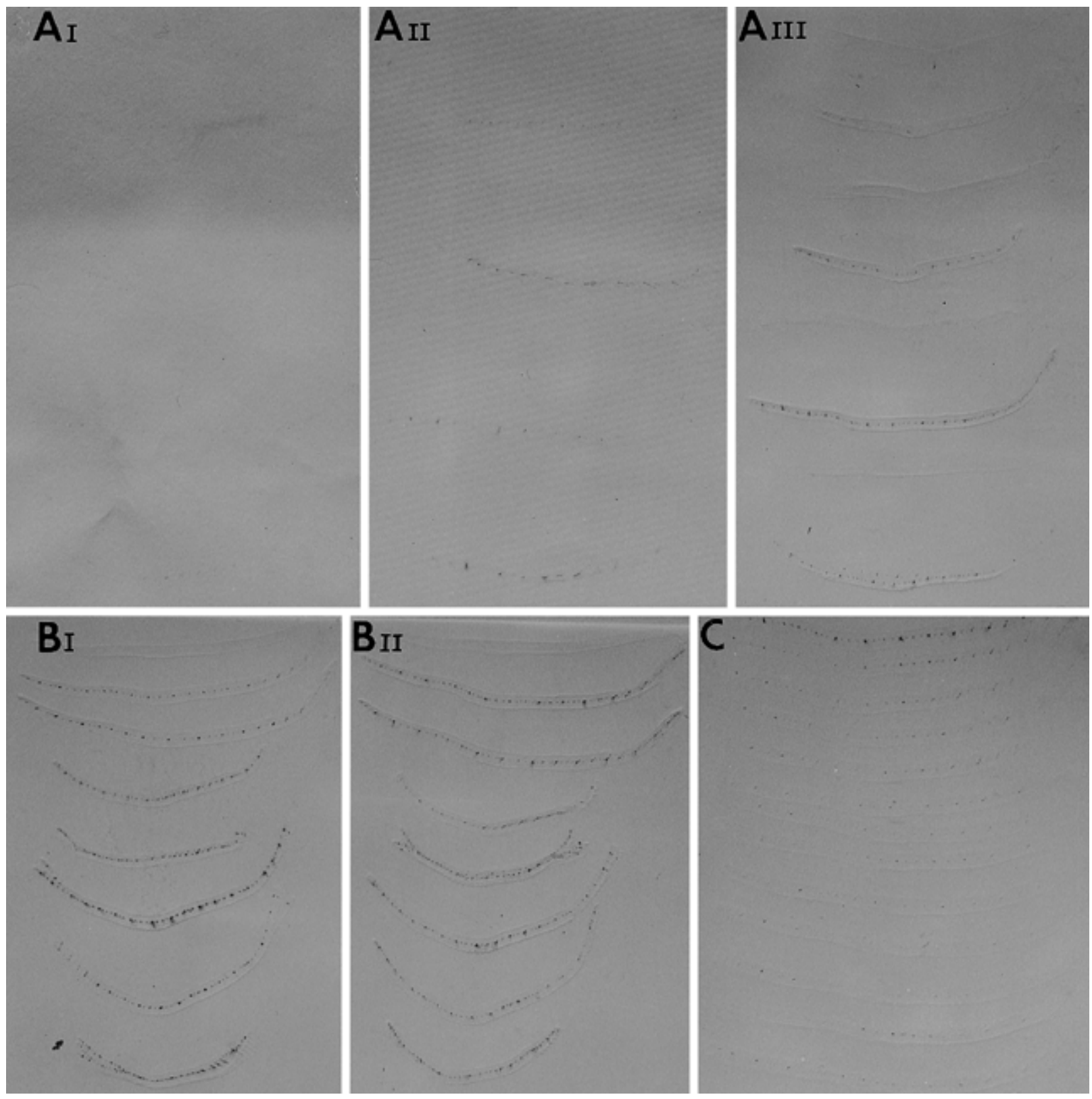

Fig. 4. Tissue blots of cross sections of pineapple closterovirus (PCV)-infected pineapple leaves. (A) Comparison of three membranes: (I) Nitropure, (II) Immobilon P, and (III) Nitro ME nitrocellulose. (B) Comparison of blots stored at $21^{\circ} \mathrm{C}$ for (I) 1 day and (II) 45 days. (C) Detection of PCV antigen in consecutive blots (from 1 to 13) from a single cut surface of a PCV-infected pineapple leaf. The blots were probed with anti-PCV monoclonal antibody. 
Samples collected from symptomatic plants consistently had higher PCV infection rates than did samples from symptomless plants of the same cultivar and from the same location. More than $99 \%$ of the crowns from symptomatic plants were positive for PCV versus $33 \%$ for crowns of asymptomatic plants (Table 1). This observation suggests that PCV may be involved in the etiology of MWP. If PCV were not involved in MWP, then the percentage of PCV-positive plants with or without symptoms should have been similar. Because only $49 \%$ of the symptomatic parent plants tested positive for PCV compared with $99 \%$ of their respective crowns, this result also indicates that crowns should be tested to determine virus incidence.

Our results support previous findings $(9,12,13)$ that PCV is widespread in symptomless pineapple plants (Tables 2). These results could support the hypotheses that PCV alone does not cause MWP and that the disease has a complex etiology involving more than one organism (e.g., another virus) or interactions between PCV and stress caused by mealybug feeding (i.e., insect toxins). Recently, badnaviruslike particles were found in pineapple in Australia and Hawaii $(8,13)$. The closterovirus, badnavirus, and possibly toxins injected by mealybugs during feeding may all contribute to the development of mea- lybug wilt of pineapple. Development of the fast, reliable assay reported here provides an important tool needed to solve the etiology of MWP.

\section{ACKNOWLEDGMENTS}

We thank C. Oda and V. Tyrell of Del Monte Fresh Produce (Hawaii) Inc., J. Liu and M. McClean at Dole Fresh Fruit Co., and H. Fleisch and the Agricultural Research Department of Maui Land and Pineapple Company Ltd. for assistance in collection of pineapple samples. We thank W. Borth, A. Hadidi, and J. Uyemoto for their suggestions in preparation of this manuscript. This work was supported in part by a grant from the State of Hawaii Governor's Agricultural Coordinating Committee (Contract No. 87-12) and by the Specific Cooperative Grant agreement 58-5320-5604 between the USDA and the University of Hawaii. This is Journal Series 4291 of the Hawaii Institute of Tropical Agriculture and Human Resources.

\section{LITERATURE CITED}

1. Carter, W. 1933. The pineapple mealy bug, Pseudococcus brevipes, and wilt of pineapples. Phytopathology 23:207-242.

2. Carter, W. 1963. Mealybug wilt of pineapple: A reappraisal. Ann. N.Y. Acad. Sci. 105:741764.

3. Garnsey, S. M., Permar, T. A., Cambra, M., and Henderson, C. T. 1995. Direct tissue blot immunoassay (TBIA) for detection of citrus tristeza virus (CTV). Pages 39-50 in: Proc. IOCV Conf., 12th.

4. German, T. L., Ullman, D. E., and Gunasinghe, U. B. 1992. Mealybug wilt of pineapple. Adv. Dis. Vector Res. 9:241-259.

5. Gunasinghe, U. B., and German, T. L. 1989.
Purification and partial characterization of a virus from pineapple. Phytopathology 79:1337-1341.

6. Hsu, H. T., and Lawson, R. H. 1991. Direct tissue blotting for detection of tomato spotted wilt virus in Impatiens. Plant Dis. 75:292295.

7. Hu, J. S., Gonsalves, A., Sether, D., and Ullman, D. E. 1992. Detection of pineapple closterovirus, a possible cause of mealybug wilt of pineapple. Acta Hortic. 334:411-416.

8. Hu, J. S., Sether, D., Lockhart, B. E. L., and Ullman, D. E. 1997. Mealybug wilt of pineapple: Pineapple viruses and two-step hea treatment of pineapple crowns. Acta Hortic. In press.

9. Hu, J. S., Sether, D. M., and Ullman, D. E. 1996. Detection of pineapple closterovirus in pineapple plants and mealybugs using monoclonal antibodies. Plant Pathol. 45:829-836.

10. Lin, N. S., Hsu, Y. H., and Hsu, H. T. 1990 Immunological detection of plant viruses and mycoplasmalike organisms by direct tissue blotting on nitrocellulose membranes. Phytopathology 80:824-828.

11. Rohrbach, K. G., Beardsley, J. W., German, T. L., Reimer, N. J., and Sanford, W. G. 1988 Mealybug wilt, mealybugs, and ants on pineapple. Plant Dis. 72:558-565.

12. Ullman, D. E., German, T. L., Gunasinghe, U. B., and Ebesu, R. H. 1989. Serology of a closteroviruslike particle associated with mealybug wilt of pineapple. Phytopathology 79:1341-1345.

13. Wakman, W., Teakle, D., Thomas, J. E., and Dietzgen, R. G. 1995. Presence of a closterolike virus and a bacilliform virus in pineapple plants in Queensland. Aust. J. Agric. Sci. 46:947-958. 